Ethiopian Journal of Environmental Studies \& Management 7(3): 298 - 304, 2014.

ISSN:1998-0507

doi: http://dx.doi.org/10.4314/ejesm.v7i3.9

Submitted: January 27, 2014

Accepted: April 23, 2014

\title{
ASSESSMENT OF WASTE STABILIZATION PONDS (WSP) EFFICIENCY ON WASTEWATER TREATMENT FOR AGRICULTURE REUSE AND OTHER ACTIVITIES A CASE OF DODOMA MUNICIPALITY, TANZANIA
}

\author{
*MKUDE, I.T. AND SARIA, J. \\ Department of Environmental Studies, The Open University of Tanzania P. O. Box 1944, Dodoma, \\ Tanzania.
}

\begin{abstract}
This study aims to assess the parameters removal efficiency of waste stabilization ponds of Swaswa area in Dodoma municipality. The study was done by analysing nine parameters in groups of biochemical and nutrients parameters. One year (2010) analysis was done in monthly intervals from January to December. Some of parameters were analysed in situ while the rest are taken to Dar es Salaam for laboratory analysis where by the water samples were taken in $4^{\circ} \mathrm{C}$ equipment for transportation. Results show very low removal efficiency for most of parameters from no removal at all to $26.7 \%\left(B O D_{5}, p H, T D S, E . C\right.$, Total alkalinity, and Total hardness, $\mathrm{NO}_{3}-\mathrm{N}$ and $\mathrm{PO}_{4}-\mathrm{P}$ ) from the influent to the final effluent. Only turbidity shows an excellent removal of 98.8\%. The removal efficiencies were also compared to general removal efficiencies from other studies and find out results from this study are very low. This low removal efficiency may be due to incomplete construction of Swaswa ponds where the third stage of maturation is missing. This stage is essential for polishing water and nutrient as well as pathogen removal. There is need of frequent awareness campaign to a community for the reuse of wastewater for agriculture and its possible impacts. Ponds should be modified and addition of maturation ponds constructed. Further studies are required for pathogen removal assessment and impacts of reuse wastewater to the food crops.
\end{abstract}

Key Words: waste stabilisation ponds, wastewater reuse, agriculture, removal efficiency, biochemical parameters, nutrients

\section{Introduction}

Most arid and semi-arid regions especially in developing countries in Africa experience severe shortage of water. This condition encourages the search for alternative sources of water. Moazzam and Khan (2007) pointed out the possibilities of domestic wastewater reuse considerations, but it must be done after several treatment processes. In many regions of the world this technology has been used as an additional renewable and reliable source of water for irrigation purpose (Angelakis et al., 2003 and Oron, 2003). Wastewater effluents if well treated can make a good contribution to water conservation and expansion of irrigated agriculture, taking on an economic dimension. It also solves disposal problems aimed at protecting the environment and public health by preventing surface water pollution (Papadopoulos and Savvides, 2003). Wastewater reuse requires effective treatment and measures to protect public health and the environment at a feasible cost (Moazzam and Khan, 2007; Sipala, et al., 2003; Anderson, et al., 2001). However, data on economic potential of Waste Stabilization Ponds (WSP) effluent is insufficient. There is still a risk of contamination of crops and soil irrigated with the effluent of WSP (Alcalde et al., 2003).

Selection of proper treatment technology is needed in developing tropical and subtropical countries where the high costs of conventional treatment plant are not affordable. Waste stabilization ponds (WSP) technology is one of the most appropriate extensive wastewater treatment methods due to their low operation and maintenance costs coupled with effective pathogens removal. The WSP technology is widely employed, despite its need of large spaces for construction (Mara and Pearson 1998; Alcalde et al., 2003; Khan and Ahmed 1992). Wastewater character is another issue to consider as it can fall into four different groups according to its $\mathrm{BOD}_{5}$ amount; weak $(<200 \mathrm{mg} / \mathrm{l})$, medium

*Corresponding Author: Mkude, I.T.

Email: isabela.thomas@yahoo.com 
$(350 \mathrm{mg} / \mathrm{l})$, strong $(500 \mathrm{mg} / \mathrm{l})$ and very strong $(>750 \mathrm{mg} / \mathrm{l})$ (Mara, 2003). Climatic factors are major considerations on selection of a WSP system. Factors like temperature and solar radiation favour microbial growth because wastewater consists of organic matter whose degradation largely depends upon microbial activity. Mara and Pearson (1998) pointed out that hot climate is ideal for pond operation.

Development activities on WSP are mostly based on loading rate; retention time, pond depth, solar radiation, total sunshine hours, wind velocity and rain fall (Mara, 1987; Curtis and Mara, 1994; Ellis and Rodrigues 1995a, 1995b).

Dodoma, capital of Tanzania lies between $6^{\circ}$ $00^{\prime}$ and $6^{\circ} 30^{\prime}$ South and $35^{\circ} 30^{\prime}$ and $36^{\circ} 02^{\prime}$ East, covers an area of $2769 \mathrm{~km}^{2}$ of which $542 \mathrm{~km}^{2}$ is built up area. The climate is characterized by a long three seasons lasting between April and early December and a short single wet season occurring during the remaining month with average coverage rainfall $570 \mathrm{~mm}$ and about $85 \%$ of this fall in the months between December and April and average maximum and minimum is $31^{\circ} \mathrm{C}$ and $18^{\circ} \mathrm{C}$ respectively. In June to August, temperature is high during the afternoon up to $35^{\circ} \mathrm{C}$ and experiencing the chilly nights on hilly areas to $10^{\circ} \mathrm{C}$ (Dodoma profile, 2003).

The regional is characterized with bush or thickets type which is widespread throughout the area wherever the natural plants covers has been altered by district factors depression and sometimes mixture of Gilles mixed with wood plants. Swaswa area has a population of 831 people but recently is estimated that it has more than 1300 inhabitants (Census, 2002). This is due to the high rate of urbanization, fuelled by massive rural-urban migration, rising in urban poverty, urban agriculture practiced for income and employment generation, food security, advantages of urban environment for producers, including availability of cheap input such as wastewater and rise in food prices (WORLD BANK, 2008). The driving force makes poor people to migrate from urban to peri-urban areas. People who are living around the Swaswa wastewater stabilization ponds used the wastewater for socio-economic activities (Mghase, 2010).

The sewerage system of Dodoma municipality serves about 40,000 people at the moment which is only about $10 \%$ of its full capacity. It has a maximum diameter of $1000 \mathrm{~mm}$, maximum flow of $3,672 \mathrm{~m}^{3} /$ hour and length of $24.3 \mathrm{~km}$. The trunk sewer has a capacity of serving 423,000 people. Some few areas are completely covered by lateral sewers of $23 \mathrm{~km}$ length and $250 \mathrm{~mm}$ in diameter. Wastewater from this system is finally treated by WSP which are located in Swaswa area. There are four waste stabilization ponds that covering an area of $40,000 \mathrm{~m}^{2}$ with $200 \mathrm{~m}$ by $200 \mathrm{~m}$ and depth of $1.5 \mathrm{~m}$ each. The ponds have capacity of serving wastewater from 68,000 people only. Two of the ponds though in use, are not yet fully constructed. The effluent from WSP is used by farmers for rice farms irrigation (DUWASA, 2010; Mghase, 2010).

The different types of WSP can be used individually, but the most efficient and common system generally consists of three stages in series: first an anaerobic, then a facultative pond and finally an aerobic or maturation pond. Anaerobic and facultative ponds are designed for BOD (Biological Oxygen Demand) removal and maturation ponds for pathogen removal, although some BOD removal occurs in maturation ponds and some pathogen removal in anaerobic and facultative ponds (SSWM, 2012). Structure of Dodoma WSPs consists of two anaerobic and two facultative ponds working in series only, no maturation stage at all.

\section{Statement of Problem}

Waste stabilization pond (WSP) is one among wastewater treatment technologies that mainly used in hot country like Tanzania and perform well in pathogen and nutrient removal, leaving the effluent being nutrient-rich for agriculture. This will be met when the ponds were well designed and performing to the fully designed capacity. WSP that receive wastewater of Dodoma municipality was designed long time considering the number of people presented in that time. The ponds were constructed in 1979 for temporally serving before the permanent WSP to be constructed at Nzuguni area. Unfortunately, the ponds are still being used regardless the increase of population from that used during designing more than 30 years ago. Apart from two of four present ponds being not fully constructed, the systems have currently showed different problems on performances such as: lack 
of maturation ponds, which is a third process on the WSP system to remove nutrients and reduce fecal coliform. Other problems are frequent blockages due to solid waste entering into the system, shortage of unblocking tools and equipment together with shortage of funds to desludge the ponds. The effluent from WSP is discharged in the downstream valley where it is used by the community for irrigated agriculture in rice farms.

The assessment on quality of WSP effluent gives out clear picture on what quality of water that has been used for agriculture of food crops. This study was assessing the quality of wastewater influent and effluent in terms of physical-chemical, biochemical and bacteriological performances. The results presented the efficiency of WSP and give the necessary recommendations on their performances and the use of wastewater for agriculture.

\section{Research Question}

What is the efficiency of Waste Stabilisation Ponds (WSP) used for urban wastewater treatment which finally being reused for irrigation and other activities?

\section{Objectives}

This study was undertaken to examine the efficiency of WSP on the treatment of wastewater that finally used for urban agriculture and other activities that need second quality water. The broad objective of this study is to assess the efficiency of waste stabilization ponds by determining the quality of wastewater influent and effluent and to propose the proper procedures for upgrading their performances. To fulfil the main objective, there are several specific objectives which are;

To quantify the biochemical parameters and nutrients of wastewater influent and effluent points of WSP.To perform the efficiency assessment of WSP for biochemical and nutrients parameters. Lastly is to propose the proper procedures for upgrading pond performance.

\section{Material and Methods Research Design}

This research was conducted as a cross sectional single case study, by using qualitative and quantitative data collection approaches. The case of this study was waste stabilisation ponds
(WSP) of Dodoma municipality. It was a single case study because it involves a single area to be studied bounded in a specific time, and with a single reference period of study as cross sectional design. The phenomenon within the case was the efficiency of WSP on the wastewater treatment that used for the irrigation. The relevant stakeholders involved throughout of the study was the local communities in Swaswa area near the WSPs that use treated wastewater for irrigation, government officials in water utility (DUWASA) and all those who were involved.

\section{Data Collection Methods}

Since it was a case study, multiple sources of data were involved to obtain a desirable relevant data. Two data types (primary data and secondary data) were collected from different data sources. For primary data, qualitative and quantitative data were collected. The qualitative data for WSP performances obtained by an interview at Dodoma urban water and sewerage authority (DUWASA) office while the quantitative data were obtained by laboratory analysis. Secondary data obtained from different previous data sources like research reports, journals, text book, census book, planning reports, and all relevant information to gather all required data mainly through internet and from DUWASA documents. The literature review was conducted to obtain the most relevant information on water and wastewater management in Dodoma municipality.

\section{Experimental Methods}

\section{Sampling and in-situ analysis}

Water grab samples were collected in polyethylene bottles on a monthly basis (once in a month) throughout the year (early January to early December 2010) at the influent and effluent locations of ponds. In situ measurements were done for Electrical conductivity (EC) and $\mathrm{pH}$ by using HQ 30d and KTO, SENSION 156 equipment for temperature, conductivity and total dissolved solids (TDS). Samples for laboratory analysis were stored in sterilized polyethylene bottles at $4^{\circ} \mathrm{C}$ and transported to Dar es Salaam for analysis at Ministry of water laboratory (Ubungo) for $\mathrm{BOD}_{5}$, Turbidity, Total Alkalinity, Total Hardness, $\mathrm{NO}_{3}-\mathrm{N}$ and $\mathrm{PO}_{4}-\mathrm{P}$. Detailed information on analytical methods is available in Ahearn et al. (2004). To obtain the total efficiency of WSP, the wastewater samples were 
collected at the influent and effluent points of the pond.

\section{Laboratory Analysis}

At Ubungo laboratory the wastewater samples analysed immediately on the arrival. The analysis was done for $\mathrm{BOD}_{5}$, Turbidity, Total Alkalinity, Total Hardness, $\mathrm{NO}_{3}-\mathrm{N}$ and $\mathrm{PO}_{4}-\mathrm{P}$ by using mass spectrophotometer. Analysis for all parameters was done according to the Standard Methods for the Examination of Water and Wastewater (APHA 1992).

\section{Statistical Analysis}

Microsoft Excel program was used for analysis of statistical values; average and their standard deviations. To evaluate the performance of each pond removal efficiencies for all the parameters monitored were computed on the basis of concentration. The concentration-based efficiency $(E)$ was computed according to Equation (1) below (ref.).

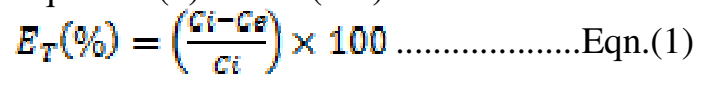

Where:

$E_{T}$ is Total efficiency of the ponds

$\mathrm{Ci}$ is influent concentration to the ponds

$\mathrm{Ce}$ is effluent concentration from the pond

\section{Results and Discussion}

The average temperature in the coldest and hottest situation was observed to be $16^{\circ} \mathrm{C}$ and $29^{\circ} \mathrm{C}$ respectively. This condition is within one of the reported to be the good condition for the WSP functioning (Mara and Pearson, 1998). The average wastewater flow rate during this study was $4,690 \mathrm{~m}^{3} /$ day (EWURA, 2010). The annual mean values of analysed parameters are presented in table 1 . The mean values are for the influent to the anaerobic pond, its effluent which is also the influent to the facultative pond and the total effluent from the facultative ponds. Total removal efficiency for each parameter was calculated and results presented in table 1 .

Table 1: Annual average results of analysed grab samples from the ponds

\begin{tabular}{lllllll} 
& & $\begin{array}{l}\text { Influent to } \\
\text { Anaerobic } \\
\text { pond }\end{array}$ & $\begin{array}{l}\text { Influent to } \\
\text { Facultative } \\
\text { pond }\end{array}$ & $\begin{array}{l}\text { Removal } \\
\text { efficiency of } \\
\text { anaerobic pond }\end{array}$ & $\begin{array}{l}\text { Effluent from } \\
\text { Facultative } \\
\text { pond }\end{array}$ & $\begin{array}{l}\text { Total Removal } \\
\text { Efficiency }(\%)\end{array}$ \\
\hline 1 & Parameters & 971.17 & 920.33 & 5.23 & 849.08 & 12.6 \\
2 & E.C ${ }^{*} \mu \mathrm{Sg} / \mathrm{cm}$ & 1768.17 & 1628.67 & 7.89 & 1538.83 & 13.0 \\
3 & Temp ${ }^{\circ} \mathrm{C}$ & 24.46 & 24.24 & & 24.38 & \\
4 & BOD $_{5} \mathrm{mg} / \mathrm{l}$ & 27.89 & 38.71 & 0 & 29.25 & 0 \\
5 & pH & 8.05 & 7.91 & 1.74 & 7.79 & 98.8 \\
6 & Turbidity NTU & $>4000$ & $>4000$ & 0 & 44.97 & 13.4 \\
7 & Total Alkalinity mg/l & 643.17 & 676.67 & 0 & 557.17 & 26.7 \\
8 & Total Hardness mg/l & 382.58 & 283.00 & 26.02 & 280.58 & 2.7 \\
9 & $\mathrm{NO}_{3}$-N mg/l & 3.32 & 3.24 & 2.41 & 3.23 & 0 \\
10 & $\mathrm{PO}_{4}-\mathrm{P}$ mg/l & 4.78125 & 3.4 & 28.89 & & \\
\hline
\end{tabular}

*1000 $\mu \mathrm{S} / \mathrm{cm}=1 \mathrm{mg} / \mathrm{l}$

\section{Overall Ponds removal efficiencies}

Raw wastewater can be categorised into four groups of weak, medium, strong and very strong using amount of $\mathrm{BOD}_{5}$ and/or COD in its typical compositions (Mara, 2003). Raw domestic wastewater of Dodoma municipality falls into weak group based on $\mathrm{BOD}_{5}$ amount which is less than $200 \mathrm{mg} / \mathrm{l}$. Based on TDS values, wastewater is characterised as strong wastewater (Sincero et al., 2002). For weak wastewater one can assume that its treatment especially biological parameters will be easier. The WSP was able to reduce parameters in very low performances less than $50 \%$ efficiency for all. $\mathrm{BOD}_{5}$ and $\mathrm{PO}_{4}-\mathrm{P}$ show an increase and with no removal at all respectively from the influent. Other parameters have been removed at low percentage. This shows that regardless the weak wastewater $\left(\mathrm{BOD}_{5}<\right.$ $200 \mathrm{mg} / \mathrm{l})$ of a raw domestic wastewater collected, the ponds fail to reduce it and let the amount to increase due to its incomplete construction. The 
ponds show $2.7 \%$ removal of nutrient $\left(\mathrm{NO}_{3}-\mathrm{N}\right)$ from the influent to the effluent which is very low compared to the general design performance of facultative ponds according to suggestions former researches. Sperling, (2005) suggested that general removal efficiency characteristic for the facultative (in this case is the last step) should remove $75-85 \%$ of the influent $\mathrm{BOD}_{5}$.

The amount of nitrates $\left(\mathrm{NO}_{3}{ }^{-}\right)$allowed by the Tanzania standards to be discharged is $20 \mathrm{mg} / \mathrm{l}$ (TBS, 2005). The effluent contains $3.23 \mathrm{mg} / \mathrm{l}$ of $\mathrm{NO}_{3}-\mathrm{N}$ regardless the lower removal efficiency $(2.7 \%)$ the ponds fall within the allowable limit. The small amount of nitrate-nitrogen at the effluent does not give a good picture of the performance but it tells that domestic wastewater collected has low nitrate-nitrogen. Also the low performances can be because of lack of stagethree of the ponds series which is Maturation $\operatorname{pond}(s)$ to complete the removal of nutrient.

WSP has managed to reduce electrical conductivity value by $13 \%$ from annual average of $1768.17 \mu \mathrm{S} / \mathrm{cm}(1.768 \mathrm{mg} / \mathrm{l})$ to $1538.83 \mu \mathrm{S} / \mathrm{cm}$ $(1.538 \mathrm{mg} / \mathrm{l})$ for influent and effluent respectively. According to TBS, (2005) the allowed limit of EC to the effluent wastewater is $400 \mathrm{mg} / \mathrm{l}$, so the amount of measured EC is within the required standard. The WSPs have shown an excellent removal of turbidity by reducing more than 4000 NTU at the influent of the first and second steps to the $44.97 \mathrm{NTU}$ at the final effluent which is almost $98.8 \%$ removal.

Wastewater $\mathrm{pH}$ ranges from $6.8-8.5$ in average which is the essential range for the desirable bacteria (TBS, 2005). In this study, wastewater $\mathrm{PH}$ ranges from 8.05 at the influent to 7.79 at the effluent. The range of $\mathrm{PH}$ at all stages is within the required amount.

In a comparison to what has already been studied, the general pond removal performances to some parameter have been suggested by Sperling, (2005) as shown in table 2 below. This parameter compared with this study to give a general idea of how the ponds of the same type can perform. Dodoma facultative ponds show poor performances in all analysed parameters (BOD, N, and P).

This low amount of parameters at the effluent might give promising results of pond removal efficiency. In a contrary, the ponds show the poor performances on removing some parameters. This may be explained because of two reasons; the municipal wastewater collected from Dodoma comprises only domestic wastewater, which means the wastewater is quite weak and the parameters are low even from the influent. The other reason is because of poor construction and partial completion of WSP stages (no maturation pond as a last stage).

Table 2: General characteristics of the main pond performance system

\begin{tabular}{lllll}
\hline & \multicolumn{3}{l}{ Pond Removal efficiency $(\%)$} & \\
\hline Parameter & Facultative pond & $\begin{array}{l}\text { Maturation } \\
\text { pond }\end{array}$ & $\begin{array}{l}\text { Facultative } \\
\text { (This study) }\end{array}$ & pond \\
\hline BOD & $75-85$ & $80-85$ & 0 \\
COD & $65-80$ & $70-83$ & N/A & \\
SS & $70-80$ & $73-83$ & N/A & \\
Ammonia & $<50$ & $50-65$ & N/A & \\
N & $<60$ & $50-65$ & 2.7 \\
P & $<35$ & $>50$ & 0 & \\
Coliforms & $90-99$ & $99.9-99.999$ & N/A & \\
\hline
\end{tabular}

Source: Adapted from Sperling, (2005), N/A=not applicable 
Effluent quality and the standards

Table 1: Overall effluent from the pond with comparison to TBS

\begin{tabular}{|c|c|c|c|}
\hline Parameters & Units & $\begin{array}{l}\text { Total annual average on Outlet } \\
\text { (Effluent from Facultative pond) }\end{array}$ & TBS standards \\
\hline TDS & & 849.08 & 3000 \\
\hline E.C & $\mu \mathrm{S} / \mathrm{cm}$ & $1538.83(1.54 \mathrm{mg} / \mathrm{l})$ & $400^{*}$ \\
\hline $\mathrm{BOD}_{5}$ & & 29.25 & 30 \\
\hline $\mathrm{PH}$ & & 7.79 & $6.5-8.5$ \\
\hline Turbidity & NTU & 44.97 & 300 \\
\hline T.Alk & $\mathrm{mg} / \mathrm{l}$ & 557.17 & N/A \\
\hline T.Hard & $\mathrm{mg} / \mathrm{l}$ & 280.58 & N/A \\
\hline $\mathrm{NO}_{3}-\mathrm{N}$ & $\mathrm{mg} / \mathrm{l}$ & 3.23 & $<0.5$ \\
\hline $\mathrm{PO}_{4}-\mathrm{P}$ & $\mathrm{mg} / \mathrm{l}$ & 4.78125 & N/A \\
\hline
\end{tabular}

Source: TBS, (2005)

Quality of wastewater effluent was then compared to the effluent standards of Tanzania Bureau of Standards (TBS). Table 3 shows the summary of amounts of analysed parameters together with that allowable limit from TBS. Most of analysed parameters (TDS, E.C, $\mathrm{BOD}_{5}$, $\mathrm{pH}$ and Turbidity) are within the required limits. Only $\mathrm{NO}_{3}-\mathrm{N}$ does not meet the required amount of $<0.5 \mathrm{mg} / \mathrm{l}$. The rest of the parameters (Total alkalinity, total hardness and PO4-P) have no TBS limits available for comparison.

\section{Conclusion}

Based on this study, it can be concluded that, wastewater to waste stabilization ponds show high amount of biochemical parameters $\left(\mathrm{BOD}_{5}\right.$, PH, Turbidity, TDS, E.C, Total alkalinity, and Total hardness on the influent point, and little different on the effluent. The quantity of nutrients $\left(\mathrm{NO}_{3}-\mathrm{N}\right.$ and $\left.\mathrm{PO}_{4}-\mathrm{P}\right)$ of wastewater at the influent is almost the same from that of effluent from the WSP.

One of the most important problem of the WSP is the very low overall removal efficiencies of WSP for all analysed parameters (biochemical and nutrients), ranging from $0 \%$ to $27 \%$.Only turbidity has been removed by $98.8 \%$. In a comparison with Tanzania Bureau Standards of wastewater to be disposed of or reused, most of effluent parameters meet the required thresholds.

This low amount of parameters at the effluent might give promising results of pond removal efficiency. In a contrary, the ponds show the poor performances on removing some parameters. This may be explained because of two reasons; the municipal wastewater collected from Dodoma comprises only domestic wastewater, which means the wastewater is quite weak and the parameters are low even from the influent. The other reason is because of poor construction and partial completion of WSP stages (no maturation pond as a last stage), which is another important problem of the pond.

There is need of upgrading the performance of this pond for better removal. This might be done by frequent desludging of present ponds where necessary and additional of a third stage (maturation) especially for nutrients and pathogen removal. Also frequent maintenance is required for the present ponds to make sure they are performed to the required designed level. Frequently awareness campaigns to a community are required for wastewater reuse in agriculture, especially for the food and vegetables that are directly eaten. Further research is required for the pathogen removal and impact of reused wastewater to those crops at Swaswa area.

If the wastewater is well treated by the ponds, there is opportunity of wastewater reuse especially to the uses that do not need drinking water quality, like car wash, gardening and other cleaning purposes.

\section{Acknowledgment}

The authors extend their acknowledgements to the wastewater engineer of DUWASA and all those who participated in one way or another

\section{References}

Alcalde, L., G. Oron, L. Gillerman, M. Salgot and Y. Manor. (2003). Removal of faecal coliforms somatic coliphages and F- 
specific bacteriophages in a stabilization pond and reservoir system in arid regions. Wat. Sci. Tech., 3: 177-184

Angelakis, A.N., Bontoux, B., and Lazarova, V. (2003). Challenges and prospectives for water recycling and reuse in EU countries. Water Supply, IWA Publishing Vol 3 No 4 pp 59-68

APHA (American Public Health Association), American Water Works Association (AWWA), Water Environment Federation (WEF), (1992). Standard Methods for the Examination of Water and Wastewater, 20th ed. APHA Publishers, Washington, DC.

Curtis, T.P. and Mara, D.D. (1994). The Effect of Sunlight on Mechanisms for the Die-Off of Faecal Coliforms Bacteria in Waste Stabilization Ponds. Research monograph $n^{o}$ 1. ed.. Mara, D.D. and Hadlington, S. Leeds: University of Leeds.

Dodoma Urban Water and Sanitation Authority (DUWASA). (2010). Water quality monitoring program report. Dodoma

Khan, M. A. and Ahmad, S.I. (1992). Performance evaluation of waste stabilization ponds in subtropical region. Wat. Sci. Tech., 26: 1717-1728.

Mara, D.D. and Pearson, H.W. (1998). Design Manual for Waste Stabilization Ponds in Mediterranean Countries. European Investment Bank. Mediterranean Environmental Technical Assistance
Programme. Lagoon Technology International Leeds, UK.

Mghase, E.I. (2010). The benefit of wastewater utilization, case study of Swaswa area in Dodoma Municipality. BSc dissertation report. Institute of Rural Development and Planning, Dodoma.

Moazzam Ali Khan, S. Shahid Shaukat, Atif Shahzad and Hamda Arif. (2012). Growth And Yield Responses Of Pearl Millet (Pennisetum Glaucum [L.] R.Br.) Irrigated With Treated Effluent From Waste Stabilization Ponds. Pak. J. Bot. 44(3): 905-910,

Papadopoulos, I. and Savvides, S. (2003). Optimization of the use of nitrogen in the treated wastewater reuse for irrigation. Wat. Sci. Technol., 3: 217-221.

Sipala, S., Mancini, G., and Vagliasindi, F.G.A. (2003). Development of a web-based tool for the calculation of costs of different wastewater treatment and reuse scenarios. Water Supply, 3(4): 89-96.

Sperling, M.W. (2005). Modelling of coliform removal in 186 facultative and maturation ponds around the world. Water Res., 39: 5261-5273.

Scheierling, S.M. (2008). Water Anchor, World Bank World Water Week Seminar: New Frontiers of Sanitation, Stockholm.

Sustainable Sanitation and Water Management (SSWM), (2012). Advanced Integrated Ponds. An integrative tool for capacity development on the local level, Basel. 